\title{
STUDI KERAGAMAN CENDAWAN ENTOMOPATOGEN DARI BERBAGAI RIZOSFER TANAMAN HORTIKULTURA DI KOTA PADANGSIDIMPUAN
}

\author{
Muhammad Agung Permadi ${ }^{1}$, Rafiqah Amanda Lubis ${ }^{1}$, Isrong Kinarang \\ Siregar \\ ${ }^{1}$ Program Studi Agroteknologi, Fakultas Pertanian Universitas Muhammadiyah Tapanuli Selatan \\ email: muhammad.agungp@um-tapsel.ac.id
}

\begin{abstract}
Entomopathogenic fungi often used as bioinsecticides to control pest insects. Entomopathogenic fungi infect through penetrating cuticles of insect or inedible. Entomopathogenic fungi can be found in the rhizosphere. The purpose of this study was to explore the types of entomopathogenic fungi in various rhizosphere of horticultural plants in Padangsidimpuan. This research was conducted at the Agrotechnology Laboratory, Faculty of Agriculture, South Tapanuli Muhammadiyah University. The results showed that the use of Tenebrio molitor as bait, can effectively obtain entomopathogenic fungi from the soil. The highest mortality of Tenebrio molitor where infected by entomopathogenic fungi was $64 \%$ on soybean plant and the lowest mortality due to infection of entomopathogenic fungi was $11 \%$ on mustard plants. There was only one genus of entomopathogenic fungi found in this study was Metarhizium sp.
\end{abstract}

Keywords: soil, Metarhizium, Tenebrio molitor, infect, moist chamber

\begin{abstract}
Abstrak
Cendawan entomopatogen merupakan mikroorganisme yang sering digunakan sebagai bioinsektisida untuk mengendalikan serangga hama. Cendawan entomopatogen menginfeksi serangga dengan cara termakan maupun menembus kutikula serangga tersebut. Cendawan entomopatogen dapat ditemukan di daerah rizosfer. Tujuan dari penelitian ini adalah untuk mengetahui cendawan entomopatogen yang terdapat pada berbagai rizosfer tanaman hortikultura di Kota Padangsidimpuan, yaitu pada rizosfer tanaman kacang panjang, tomat, jagung, kedelai, mentimun, sawi, terong, dan tanaman cabai. Penelitian ini dilaksanakan di Laboratorium Agroteknologi Fakultas Pertanian Universitas Muhammadiyah Tapanuli Selatan. Hasil penelitian menunjukkan bahwa penggunaan metode perangkap serangga dengan Tenebrio molitor sebagai umpan, efektif memancing cendawan entomopatogen yang berada dalam tanah. Mortalitas Tenebrio molitor tertinggi yang disebabkan infeksi cendawan terdapat pada tanaman kedelai sebesar $64 \%$, dan yang paling rendah pada tanaman sawi sebesar $11 \%$. Pada penelitian ini hanya ditemukan satu genus cendawan entomopatogen yaitu Metarhizium sp.
\end{abstract}

Kata kunci: tanah, Metarhizium, Tenebrio molitor, infeksi, moist chamber

\section{PENDAHULUAN}

Cendawan entomopatogen adalah organisme heterotrof yang hidup sebagai parasit pada serangga. Cendawan ini sering digunakan sebagai bioinsektisida untuk mengendalikan serangga hama selain penggunaan bakteri, virus dan nematoda. Hal ini dikarenakan cendawan entomopatogen memiliki keefektifan yang tinggi terhadap serangga hama. Cendawan entomopatogen menginfeksi serangga dengan cara 
menembus kutikula serangga tersebut, berbeda dengan virus dan bakteri yang harus termakan oleh serangga inang (Rei et al., 2014).

Indonesia diketahui memiliki keanekaragaman hayati yang tinggi sehingga memiliki keragaman cendawan entomopatogen yang cukup banyak. Keanekaragaman hayati yang tinggi ini didukung oleh wilayah Indonesia yang berada di daerah tropis tanpa perubahan suhu yang besar. Indonesia juga memiliki dua macam musim dan berbagai macam tipe habitat. Penelitian tentang keanekaragaman cendawan entomopatogen telah banyak dilakukan. Keragaman cendawan entomopatogen di hutan hujan tropik Thailand sebanyak 15 genus (Aung et al. 2008) dan dilaporkan ada 13 genus yang telah diisolasi (Luangsa-Ard et al. 2008), sedangkan di Indonesia dilaporkan 9 genus dari Telaga Warna (Amalia 2008) dan 3 genus dari Cangkuang (Herlis et al. 2009).

Tanah merupakan salah satu tempat untuk mengetahui keberadaan cendawan entomopatogen di alam. Hal ini sesuai dengan pernyataan Luangsa-Ard et al. (2006) yang menyatakan bahwa cendawan yang bersifat parasit pada serangga di alam, banyak ditemukan di dareah tropis, yaitu pada tanah yang lembap, dan pada daerah yang berbukit. Namun tidak semua cendawan entomopatogen ditemukan dalam tanah. Menurut Sapieha-Waszkiewics et al. (2005), keberadaan cendawan entomopatogen di dalam tanah tergantung pada habitatnya. Cendawan entomopatogen lebih mudah ditemukan pada daerah rizosfer. Carlile et al. (2001) menyatakan bahwa populasi organisme di rizosfer biasanya lebih banyak dan beragam dibandingkan pada tanah bukan rizosfer. Untuk mendapatkan cendawan entomopatogen yang akan digunakan sebagai agens pengendali hayati hama dapat dilakukan dengan mengisolasi dari lingkungan dimana hama target hidup. Oleh karena itu diperlukan eksplorasi cendawan entomopatogen dari berbagai rizosfer tanaman hortikultura untuk mendapatkan isolat cendawan yang efektif dalam mengendalikan hama tanaman hortikultura.

\section{METODE PENELITIAN}

\section{Tempat dan Waktu Penelitian}

Pengambilan sampel tanah dilaksanakan di beberapa Kecamatan Kota Padangsidimpuan. Isolasi dan karakterisasi fisiologis cendawan dilaksanakan di laboratorium Agroteknologi Fakultas Pertanian Universitas Muhammadiyah Tapanuli Selatan. Cendawan entomopatogen diambil dari tanah di sekitar tanaman (rizosfer) hortikultura di 8 lokasi yaitu lahan pertanaman tomat, kacang panjang, jagung, terung, kedelai, sawi, cabai dan mentimun (Tabel 1). Sampel tanah diambil pada lima titik dengan sistem diagonal dan diambil pada bulan Februari 2018.

Tabel 1. Deskripsi lokasi penelitian untuk pengambilan sampel tanah di Kecamatan Kota Padangsidimpuan

\begin{tabular}{|l|l|l|l|}
\hline No. & \multirow{2}{*}{$\begin{array}{c}\text { Jenis Tanaman } \\
\text { Hortikultura }\end{array}$} & \multicolumn{1}{|c|}{ Desa/Kelurahan } & \multicolumn{1}{c|}{ Kecamatan } \\
\cline { 3 - 4 } & & Sigulang & Padangsidimpuan Tenggara \\
\hline 1 & Tomat & Sigulang & Padangsidimpuan Tenggara \\
\hline 2 & Kacang Panjang & Pijorkoling & Padangsidimpuan Tenggara \\
\hline 3 & Jagung & Palopat PK & Padangsidimpuan Tenggara \\
\hline 4 & Terong & Losung Batu & Padangsidimpuan Utara \\
\hline 5 & Kedelai & Sitamiang Baru & Padangsidimpuan Selatan \\
\hline 6 & Sawi & Siloting & Padangsidimpuan Batunadua \\
\hline 7 & Cabai & Purwodadi & Padangsidimpuan Batunadua \\
\hline 8 & Mentimun & & \\
\hline
\end{tabular}




\section{Isolasi Cendawan Entomopatogen dari Berbagai Lahan}

Sampel tanah diambil dari rizosfer tanaman yang memenuhi kriteria pada daerah yang ditentukan. Tanah diambil dengan menggunakan sekop kecil dan digali hingga kedalaman 10-15 cm disekitar rizosfer tanaman. Pada tiap-tiap titik lokasi sampel tanah diambil sebanyak 1000 gr. Sampel tanah yang telah diambil dimasukkan ke dalam kantong plastik dan diberi label yang memuat tentang lokasi, jenis komoditi, dan tanggal pengambilan, selanjutnya sampel tanah dibawa ke laboratorium untuk dilakukan proses isolasi cendawan.

Isolasi cendawan dari tanah dilakukan dengan metode perangkap serangga (Insect baid method) menggunakan larva Tenebrio molitor (Coleoptera: Tenebrionideae). Masing-masing sampel tanah diayak dengan menggunakan ayakan 60 mesh dan dimasukkan ke dalam kotak plastik berukuran 10x15 cm, masing-masing sebanyak 500g, diberi label sesuai daerahnya. Masing-masing tanah tersebut dilembabkan dengan akuades sampai tanah kelihatan agak basah, kemudian dimasukkan 20 ekor larva T. molitor instar 5 yang baru berganti kulit ke dalam kotak yang berisi sampel tanah tersebut dan diulang sebanyak 5 kali. Kemudian larva tersebut diselimuti dengan selapis tanah yang ada di dalam kotak. Setelah itu kotak ditutup dengan potongan kain kasa. Larva T. molitor yang diduga terserang cendawan entomopatogen diamati 3 hari setelah perlakuan dan selanjutnya diamati setiap hari.

Larva yang diduga terserang cendawan diambil dan disterilisasi dengan cara sterilisasi basah dan dilanjutkan dengan moist chamber. Pertama larva dibilas dengan akuades selama 3 menit, kemudian dibilas dengan alkohol $70 \%$ selama 3 menit, dan setelah itu dibilas lagi dengan aquadest selama 3 menit. Selanjutnya larva tersebut dimasukkan ke dalam cawan petri yang berisi tisu lembab steril (moist chamber) dan diinkubasi untuk merangsang pertumbuhan cendawan entomopatogen.

\section{Perbanyakan dan Pemurnian Cendawan di Media PDA}

Prosedur pembuatan potato dextrose agar (PDA) dalam penelitian ini adalah kentang dikupas dan dicuci menggunakan air bersih. Kemudian ditimbang sebanyak $400 \mathrm{gr}$, dipotong-potong menjadi bentuk dadu kecil-kecil dan direbus dengan akuades sebanyak 1 liter sampai mendidih. Setelah matang, kentang disaring dan larutan kentang yang telah disaring dimasukkan ke dalam gelas breaker. Selanjutnya ditambahkan agar dan dextrose masing-masing sebanyak 15 gr sambil dipanaskan diaduk hingga merata, akuades ditambahkan hingga mencapai volume 1 liter jika mengalami penguapan. Setelah itu PDA cair dimasukkan ke dalam botol schott untuk sterilisasi menggunakan autoklaf. Media PDA dipadatkan dalam cawan petri yang berdiameter $9 \mathrm{~cm}$. Cendawan di inkubasi selama 21 hari pada suhu kamar.

\section{Pengamatan}

Persentase mortalitas $T$. molitor pada perlakuan. Pengamatan mortalitas $T$. molitor dilakukan dengan mengamati jumlah larva $T$. molitor yang mati pada saat perlakuan metode perangkap serangga (insect bait method), dengan rumus:

Persentase mortalitas T. molitor $=\frac{\text { Jumlah larva mati }}{\text { Jumlah larva diperlakukan }} \times 100 \%$

\section{Identifikasi Cendawan Entomopatogen}


Cendawan yang diperoleh, diidentifikasi sampai tingkat genus dengan mengamati secara makroskopis (warna, bentuk, dan arah pertumbuhan koloni) dan mikroskopis (percabangan konidiofor dan bentuk konidia cendawan) (Barnet dan Hunter 1972, Watanabe 2002).

\section{HASIL DAN PEMBAHASAN Hasil}

Mortalitas larva T. molitor yang tertinggi ditemukan pada tanah yang diambil dari lahan tanaman kedelai dengan persentase $64 \%$, selanjutnya pada lahan tanaman jagung $57 \%$, pada lahan tanaman terong $44 \%$, berikutnya berturut-turut pada lahan tanaman tomat, cabai, kacang panjang, dan mentimun dengan persentase masingmasing sebesar $41 \%, 40 \%, 26 \%$, dan $23 \%$. Mortalitas terendah ditemukan pada lahan pertanaman sawi yaitu $11 \%$. Pada gambar 1 dapat dilihat persentase mortalitas larva T. molitor pada perlakuan metode perangkap serangga.

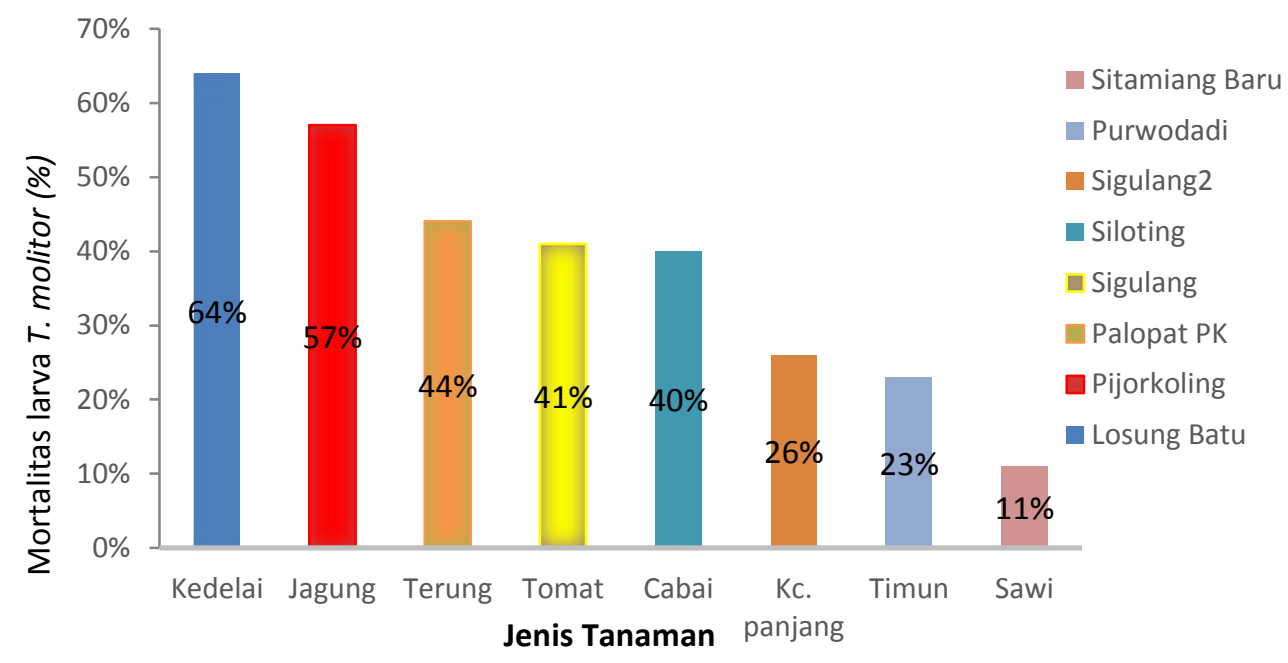

\section{Gambar 1. Persentase mortalitas larva T. molitor pada perangkap serangga}

Gejala larva T. molitor yang terinfeksi cendawan entomopatogen dapat dilihat pada gambar 2, pada hari pertama setelah kematian larva $T$. molitor belum menunjukkan tanda-tanda infeksi cendawan. Pada hari kedua, ketiga, dan keempat mulai tumbuh miselia cendawan berwarna putih menyelimuti permukaan larva $T$. molitor yang telah mati. Kemudian pada hari kelima miselia cendawan berwarna putih mengalami perubahan menjadi warna hijau.

Cendawan entomopatogen yang berhasil dikoleksi dari berbagai rizosfer tanaman hortikultura di 8 lokasi berjumlah 8 isolat. Dari hasil identifikasi cendawan entomopatogen hanya ditemukan 1 genus cendawan yaitu Metarhizium dengan karakteristik makroskopis (Tabel 2) yang berbeda. Hal ini disebabkan perbedaan jenis asal dan geografi isolat tersebut. Untuk karakteristik mikroskopis diamati bentuk konidiofor dan konidia dari genus cendawan tersebut. Karakterisitik dari cendawan Metarhizium dibuktikan secara mikroskopis (Gambar 3). Konidiofor cendawan tersusun tegak, berlapis, bercabang dan konidia tumbuh dibagian ujung konidiofor. Sedangkan konidia Metarhizium bersel satu, tidak bersepta, berbentuk silindris, konidia membentuk rantai pararel jika jumlahnya banyak, berwarna hijau terang atau kuning kehijauan. Hal ini sesuai dengan yang dikemukakan Humber (1997), Watanabe 
(2002) dan Prayogo et al. (2005). Koloni isolat cendawan Metarhizium (Gambar 4) dengan warna kuning kehijauan dan putih kehijauan.
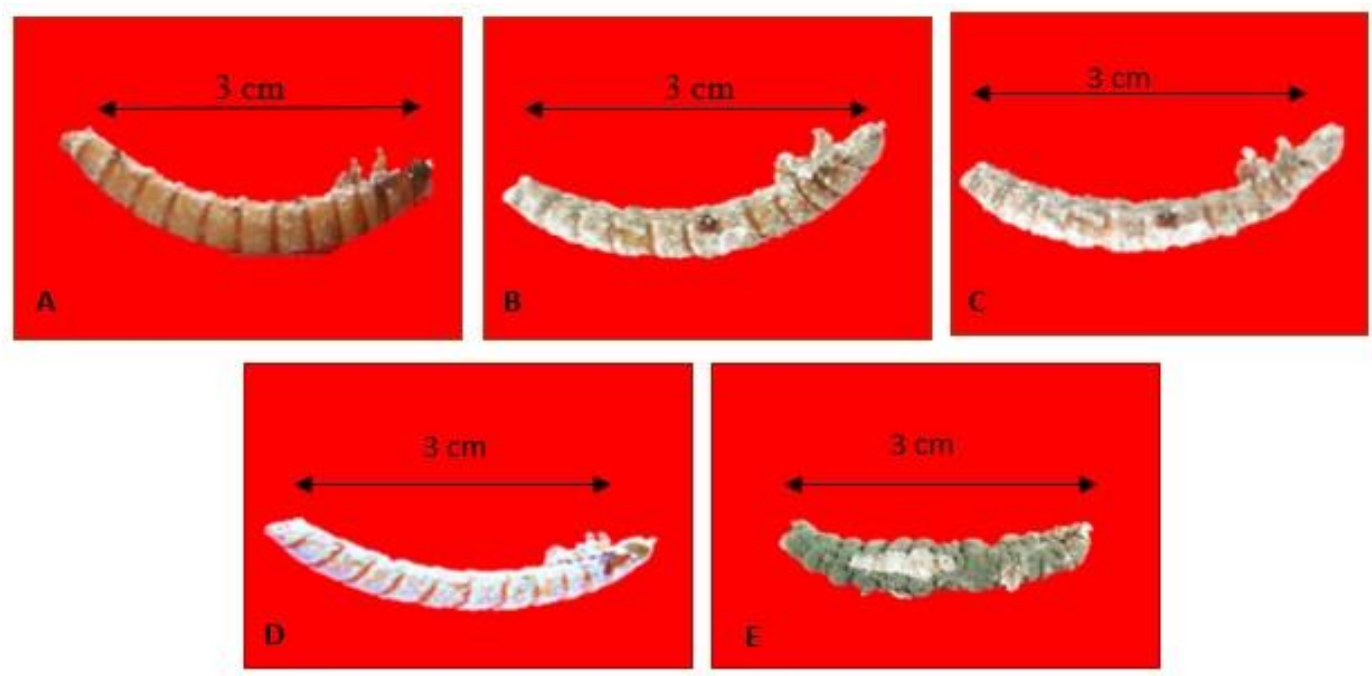

Gambar 2. Cadaver (bangkai) larva T. molitor (A) Larva yang telah mati satu hari, (B) Larva yang telah mati dua hari, (C) Larva yang telah mati tiga hari, (D) Larva yang telah mati empat hari, (E) Larva yang telah mati lima hari.

Tabel 2. Karakterisasi Morfologi Cendawan Entomopatogen Secara Makroskopis Pada Hari Ke-21 Setelah Inkubasi

\begin{tabular}{|c|c|c|c|c|c|c|c|}
\hline \multirow[b]{2}{*}{ Tanaman } & \multirow[b]{2}{*}{ Lokasi } & \multirow[b]{2}{*}{$\begin{array}{c}\text { Titik } \\
\text { koordinat }\end{array}$} & \multirow[b]{2}{*}{ Isolat } & \multicolumn{4}{|c|}{ Karakteristik makroskopis cendawan } \\
\hline & & & & $\begin{array}{l}\text { Warna } \\
\text { koloni }\end{array}$ & $\begin{array}{c}\text { Bentuk } \\
\text { koloni }\end{array}$ & $\begin{array}{c}\text { Arah } \\
\text { koloni }\end{array}$ & Genus \\
\hline Jagung & $\begin{array}{l}\text { Pijorkoling, } \\
\text { Psp } \\
\text { Tenggara }\end{array}$ & $\begin{array}{l}1.470 \\
99.251\end{array}$ & MetJP & $\begin{array}{c}\text { Putih } \\
\text { kehijauan }\end{array}$ & Melingkar & Samping & Metarizium \\
\hline Kedelai & $\begin{array}{l}\text { Losung } \\
\text { batu, } \\
\text { Psp Utara }\end{array}$ & $\begin{array}{l}1.407, \\
99.228\end{array}$ & MetKP & $\begin{array}{l}\text { Kuning } \\
\text { kehijauan }\end{array}$ & Menyebar & Samping & Metarizium \\
\hline Tomat & $\begin{array}{l}\text { Sigulang, } \\
\text { Psp } \\
\text { Tenggara }\end{array}$ & $\begin{array}{l}1.323, \\
99.305\end{array}$ & MetTmP & $\begin{array}{c}\text { Putih } \\
\text { kehijauan }\end{array}$ & Melingkar & Samping & Metarizium \\
\hline Terung & $\begin{array}{l}\text { Palopat PK, } \\
\text { Psp } \\
\text { Tenggara }\end{array}$ & $\begin{array}{l}1.343, \\
99.306\end{array}$ & MetTrP & $\begin{array}{c}\text { Putih } \\
\text { kehijauan }\end{array}$ & Menyebar & Samping & Metarizium \\
\hline $\begin{array}{l}\text { Kacang } \\
\text { panjang }\end{array}$ & $\begin{array}{l}\text { Sigulang, } \\
\text { Psp } \\
\text { Tenggara }\end{array}$ & $\begin{array}{l}1.323, \\
99.305\end{array}$ & MetKPP & $\begin{array}{c}\text { Putih } \\
\text { kehijauan }\end{array}$ & Menyebar & Samping & Metarizium \\
\hline Sawi & $\begin{array}{l}\text { Sitamiang } \\
\text { baru, } \\
\text { Psp Selatan }\end{array}$ & $\begin{array}{l}1.389 \\
99.274\end{array}$ & MetSP & $\begin{array}{c}\text { Putih } \\
\text { kehijauan }\end{array}$ & Melingkar & Samping & Metarizium \\
\hline Mentimun & $\begin{array}{l}\text { Purwodadi, } \\
\text { Psp } \\
\text { Batunadua }\end{array}$ & $\begin{array}{l}1.403, \\
99.292\end{array}$ & MetMtP & $\begin{array}{c}\text { Kuning } \\
\text { kehijauan }\end{array}$ & Menyebar & Samping & Metarizium \\
\hline Cabai & $\begin{array}{l}\text { Siloting, } \\
\text { Psp } \\
\text { Batunadua }\end{array}$ & $\begin{array}{l}1.384, \\
99.304\end{array}$ & MetCP & $\begin{array}{l}\text { Kuning } \\
\text { kehijauan }\end{array}$ & Menyebar & Samping & Metarizium \\
\hline
\end{tabular}



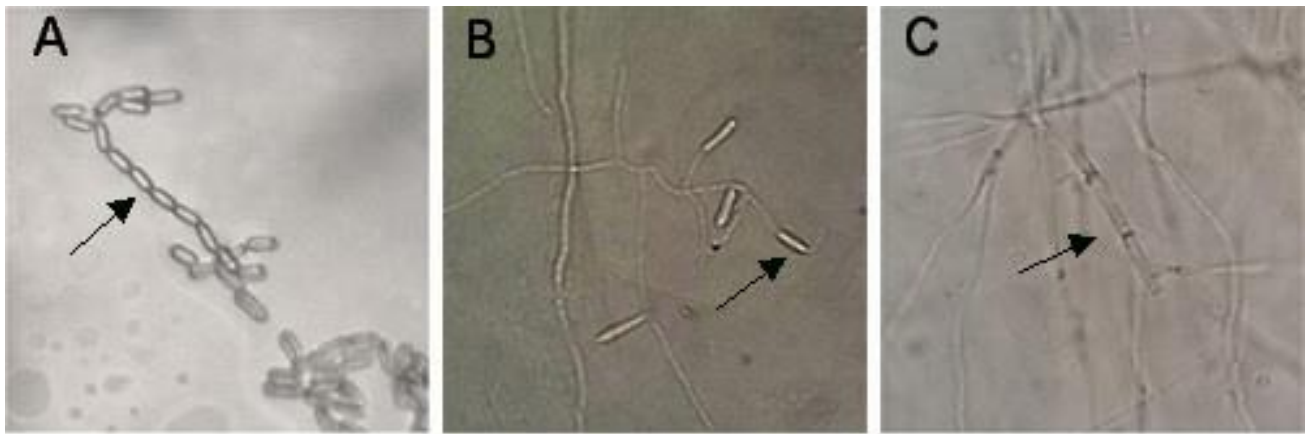

Gambar 3. Bentuk mikroskopis isolat Metarhizium, (A) Konidia berbentuk silindris dan membentuk rantai, (B) Konidiofor, (C) besepta Konidia terbentuk pada ujung konidiofor.
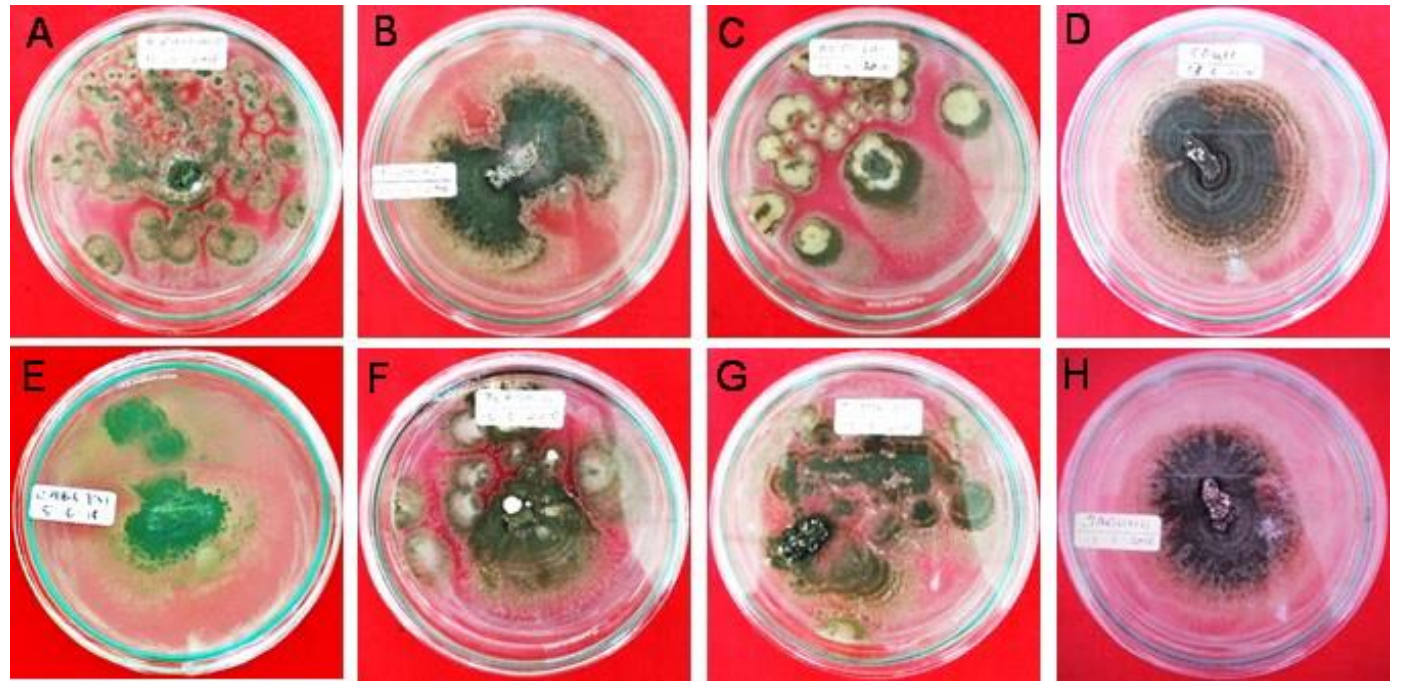

Gambar 4. Morfologi isolat Metarhizium pada hari ke-21 setelah inkubasi, (A) MetKPP, (B) MetTmP, (C) MetKP, (D) MetSP, (E) MetCP, (F) MetTrP, (G) MetMtP, (H) MetJP.

\section{Pembahasan}

Pada hari pertama sampai hari kelima pemancingan cendawan menggunakan larva T. molitor tidak ada ditemukan larva yang mati. Namun pada hari keenam mulai ditemukan larva T. molitor yang mengalami kematian. Hal ini dikarenakan kematian larva memerlukan waktu beberapa hari setelah konidia cendawan menempel pada tubuh larva. Konidia cendawan dan larva mempunyai hubungan spesifik yang bersifat biologis yang sangat dipengaruhi oleh sifat cendawan yang masuk ke dalam tubuh larva yang terinfeksi (Pracaya 2008). Setelah konidia cendawan melekat pada kutikula, selanjutnya konidia berkecambah melakukan penetrasi terhadap kutikula dan masuk ke hemosel (Untung 2006). Menurut Tanada dan Kaya (1993) periode proses awal infeksi sampai kematian serangga terjadi dalam kurun waktu yang singkat yaitu hanya 3 hari dan selambat-lambatnya 12 hari, namun pada umumnya terjadi dalam waktu 5-8 hari dan periode tersebut dapat berbeda tergantung pada ukuran inang.

Mortalitas larva $T$. molitor yang digunakan sebagai perangkap untuk mendapatkan cendawan entomopatogen pada penelitian ini yang tertinggi ditemukan pada lahan pertanaman kedelai dengan persentase 64\%. Hal ini disebabkan lahan pertanaman kedelai tersebut masih menggunakan sistem pertanian organik. Perbedaan persentase mortalitas T. molitor yang terserang cendawan entomopatogen 
berhubungan dengan aplikasi pupuk dan aplikasi pestisida yang diterapkan pada masing masing lahan. Sistem pertanian secara organik dapat mendorong tanaman dan tanah tetap sehat melalui cara pengelolahan tanah dan tanaman dengan pemanfaatan bahan-bahan organik, menghindari penggunaan pupuk buatan dan pestisida (Margolang et al. 2015). Hal ini sesuai dengan penelitian Sosa-Gomez et al. (2001) menunjukkan bahwa populasi cendawan entomopatogen pada tanah pertanaman kedelai lebih tinggi pada tanah yang tidak diolah dibandingkan dengan tanah yang diolah. Selanjutnya Margolang et al. (2015) juga menyatakan bahwa penerapan sistem pertanian organik mampu memperbaiki karakteristik sifat biologi tanah dengan meningkatkan respirasi tanah, jumlah mikroorganisme tanah, dan populasi cacing tanah.

Terdapat hubungan yang erat antara sistem pertanian organik dengan cendawan entomopatogen yang berada di dalam tanah. Salah satu faktor yang mempengaruhi perkembangan mikroorganisme tanah adalah bahan organik (Ardi 2010). Ali-Shtayeh et al. (2003) mengemukakan bahwa kandungan bahan organik tanah dan tipe vegetasi berpengaruh nyata terhadap keberadaan cendawan entomopatogen dalam tanah. Semakin lama pertanian organik diterapkan oleh petani maka semakin banyak juga cendawan entomopatogen yang hidup pada tanah tersebut karena cendawan entomopatogen mendapat asupan makanan yang cukup dari mikroorganisme di dalam tanah (Sapieha-Waszkiewics et al. 2005).

Berbeda dengan lahan pertanaman kacang panjang dan tomat yang penggunaan pestisida dan pupuk sintetis yang intensif. Hal ini terlihat dari kondisi lahan tersebut yang memiliki tanah yang keras dan kering. Selain itu pupuk sintetis juga dapat mercuni mikroorganisme tanah, sehingga menyebabkan infeksi cendawan pada lahan pertanaman kacang panjang dan tomat cukup rendah masing-masing sebesar $41 \%$ dan 26\%. Hal ini sesuai dengan yang dikemukakan oleh SapiehaWaszkiewics et al. (2005) bahwa keberadaan cendawan entomopatogen di dalam tanah sangat tergantung pada teknik budidaya dan penggunaan pestisida. Penggunaan pupuk buatan dan pestisida yang berlebihan dapat merusak tekstur dan kesuburan tanah, sehingga secara perlahan-lahan mikroorganisme dalam tanah mengalami kematian (Sapieha-Waszkiewics et al. 2005).

Pada penelitian ini hanya 1 genus cendawan entomopatogen yang ditemukan yaitu Metarhizium sp. dari rizosfer beberapa tanaman hortikultura di Kota Padangsidimpuan. Berdasarkan data yang dikeluarkan BMKG Kota Padangsidimpuan pada tahun 2017, Kota Padangsidimpuan memiliki suhu berkisar $21-27^{\circ} \mathrm{C}$ dengan kelembaban 80-83\%. Sehingga mendukung cendawan Metarhizium sp. untuk tumbuh dan berkembang karena cendawan tersebut dapat tumbuh optimal pada suhu $23-28^{\circ} \mathrm{C}$ dan kelembaban berkisar antara 80-95\%. Hasil penelitian ini serupa dengan penelitian Permadi et al. (2018) yang menemukan cendawan Metarhizium sp. dari rizofer beberapa lahan hortikultura wiayah Kabupaten Mandailing Natal. Sedangkan di luar negeri tepatnya di Thailand, Luangsa-Ard et al. (2006) melaporkan dalam penelitiannya mendapatkan 20 spesies cendawan entomopatogen dengan 7 genus diantaranya genus Metarhizium. Masih di negara yang sama pada tahun 2008 Luangsa-Ard et al. menemukan genus Metarhizium dari 13 genus cendawan yang diperoleh. Namun di negara sendiri Indonesia, Darmawan (2016) menemukan spesies cendawan entomopatogen Metarhizium anisopliae dari rizosfer beberapa lahan pertanaman tembakau di Kabupaten Jember. Selajutnya penelitian Nuraida dan Hasyim (2009) juga menemukan cendawan entomopatogen genus Metarhizium dari 7 genus cendawan yang ditemukan dari rizosfer pertanaman kubis di Kecamatan Padang 
Panjang dan Kecamatan Lembah Gumanti Sumatera Barat. Penelitian-penelitian tersebut mengindikasikan bahwa Metarhizium mudah ditemukan di daerah mana saja.

\section{KESIMPULAN}

Berdasarkan hasil penelitian dapat disimpulkan bahwa penggunaan metode umpan serangga dengan menggunakan $T$. molitor, efektif memancing cendawan entomopatogen yang berada dalam tanah. Mortalitas serangga T. molitor tertinggi pada rizosfer tanaman kedelai dari Losung Batu, Padangsidimpuan Utara yaitu sebesar $64 \%$, dan yang terendah terdapat pada rizosfer tanaman sawi dari Sitamiang Baru, Padangsidimpuan Selatan sebesar 11\%. Pada penelitian ini hanya ditemukan satu genus cendawan entomopatogen yaitu Metarhizium sp.

\section{UCAPAN TERIMAKASIH}

Penulis mengucapkan terima kasih kepada Kemenristekdikti yang telah membantu pendanaan sehingga penelitian ini dapat terlaksana.

\section{DAFTAR PUSTAKA}

Ali-Shtayeh MS, Mara'i AB, Jamous RM. 2003. Distribution, occurrence and characterization of entomopathogenic fungi in agricultural soil in the Palestinian area. Mycopathologia. 156 (3):235-244.

Amalia R. 2008. Ragam cendawan entomopatogen dikawasan Cagar Alam Telaga Warna, Cisarua Bogor [skripsi]. Bogor (ID): IPB

Aung OM, Soytong K, Hyde KD. 2008. Diversity of entomopathogenic fungi in rainforests of Chiang Mai Province, Thailand. Fungal Divers 30: 15-22.

Barnet HL, Hunter BB. 1972. Illustrated Genera of Imperfect Fungi. 3th Edition. Minnesota (US): Burgess Publishing Comp.

BKMG Padangsidimpuan. 2017. Rata-rata Suhu dan Kelembaban Udara Menurut Bulan di Kota Padangsidimpuan $2017 . \quad$ https:// padangsidimpuankota.bps.go.id/statictable/2017/01/11/168/rata-rata-suhudan-kelembaban-udara-menurut-bulan-di-kota-padangsidimpuan-2015.html. Diakses tanggal 5 September 2018.

Carlile MJ, Watkinson SC, Goodday GW. 2001. The Fungi. 2nd. New York (US): Academic Pr.

Darmawan E. 2016. Eksplorasi jamur entomopatogen Beauveria bassiana, Metarhizium anisopliae dan jamur antagonis Trichoderma sp pada beberapa sam-pel tanah pertanaman tembakau. [skripsi]. Jember (ID): UNEJ.

Herlis R, Kusumawardhani G, Nugroho IA, Aryo RK. 2009. Ragam cendawan entomopatogen di Wana Wisata Cangkuang. Bogor (ID): IPB

Luangsa-ard JJ, Tasanatai K, Mongkolsamrit S, Hywel-Jones NL, Spatafora JW 2006. The Collection, Isolation, and Taxonomy of Invertebrate-Pathogenic Fungi [Workshop Manual]. Klong Luang (TH): National Science and Technology Development Agency (NSTDA).

Luangsa-ard JJ, Tasanathai K,Mongkolsamrit S, Hywel-Jones N. 2008. Atlas of Invertebrate-Pathogenic Fungi of Thailand (Volume 2). Klong Luang (TH): National Center for Genetic Engineering and Biotechnology (BIOTEC).

Margolang RD, Jamilah, Sembiring M. 2015. Karakteristik beberapa sifat fisik, kimia, dan biologi tanah pada sistem pertanian organik. J. Online Agroteknologi. 3(2): 717-723 
Nuraida, Hasyim A. 2009. Isolasi, identifikasi, dan karakterisasi jamur entomopatogen dari rizosfir pertanaman kubis. J. Hort. 19 (4):419-432.

Permadi MA, Lubis RA, Sari D. 2018. Eksplorasi cendawan entomopatogen dari berbagai rizosfer tanaman hortikultura di beberapa wilayah Kabupaten Mandailing Natal Provinsi Sumatera Utara. Agritech. 20 (1): 23-32.

Pracaya. 2008. Petunjuk Pembuatan Biopestisida Botani. Bogor: Niaga Swadaya

Prayogo Y, Tengkano W, Marwoto. 2005. Prospek cendawan entomopatogen Metarhizium anisopliae untuk mengendalikan ulat grayak Spodoptera litura pada kedelai. J Litbang Pertanian. 24 (1): 19-26.

Rai D, Updhyay V, Mehra P, Rana M, Pandey AK. 2014. Potential of entomopathogenic fungi as biopesticides. Ind J Sci Res and Tech. 2(5):7-13.

Sapieha-Waszkiewics A, Marjanska-Cichon B, Piwowarczyk Z. 2005. The Occurrence of Entomophatogenic Fungi In The Soil From The Plantations of Black Currant and Aronia. Electronic Journal of Polish Agricultural Universities. 8 (1): 1-8

Sosa-Gomez DR, Delpin KE, Moscardi F, Farias JRB. 2001. Natural occurrence of the entomopathogenic fungi Metarhizium, Beauveria, and Paecilomyces in soybean under till and no-till cultivation systems. Neotropical Entomology. 30 (3): 407-410.

Tanada Y, Kaya HK. 1993. Insect Pathology. California (US): Academic Pr. Inc.

Untung K. 2006. Pengantar Pengelolaan Hama Terpadu (Edisi Kedua). Yogyakarta (ID): UGM Gadjah Mada University Press.

Watanabe T. 2002. Pictorial Atlas of Soil and Seed Fungi: Morphologies of Cultured Fungi and Key to Species. 2nd Edition. Boca Raton: CRC Press. 